\title{
EKONOMSKI UČINKOVITA ZDRAVSTVENA SKRB I LIJEČNIČKA POGREŠKA
}

Cilj rada je bio istražiti odgovarajuće ekonomske modele koji utvrđuju elemente optimalnog profesionalnog standarda zdravstvene skrbi, a koji stoje u supstratu ekonomski učinkovite solucije, napose s obzirom na aktualno stanje i trendove u Hrvatskoj, kao i usporedno u SAD te Italiji. U tom smislu su posebno analizirani ekonomski učinci primjene instituta građanskopravne odgovornosti zbog povrede medicinskog standarda (liječnička pogreška), a napose financijski aspekt u svom totalitetu (trošak odštete, medicinske prevencije, ukupni društveni trošak), te su izloženi refentni ekonomski modeli. Istraživanje je pokazalo da prema različitim ekonomsko-financijskim kategorijama rezultati primjene instituta građanskopravne odgovornosti u Hrvatskoj značajno odstupaju od ukupnih ekonomskih učinaka koji se ostvaruju u zemljama obuhvaćeni ovim radom, što je rezultanta smanjene učestalosti utuženja spornih slučajeva liječničkih pogreški, kao i nižeg prosječnog iznosa odštetnine i korelativnih akcesornih troškova, a što in ultima linea dovodi do komparativno nižeg ukupnog društvenog troška. Istraživanje je pokazalo da fundamentalni instrumentarij ekonomski učinovite zdravstvene skrbi u domeni odštetnopravne problematike liječničkih pogreški leži u praktičnoj provedbi pravila dužne pažnje, odnosno, odštetnopravnom sustavu. Na taj način građanskopravna odgovornost za liječničku pogrešku faktično djeluje kao zaštitni mehanizam koji svojim pravnim i ekonomskim posljedicama per consequens oblikuje zdravstveni proces tako što potiče potencijalnog štetnika (liječnik/zdravstvena ustanova) u smjeru pružanja zdravstvene uslugu u reži-

*H. Vojković, dr.sc., Sveučilište Sjever (e-mail: hvojkovic@gmail.com). Rad je primljen u uredništvo 23.05.2018. godine, a prihvaćen je za objavu 04.06.2020. godine. 
mu standarda optimalne skrbi, imajući na umu da upravo odštetnopravni sustav navedeni standard medicinskog postupanja izjednačuje sa ekonomskom kategorijom optimalne skrbi za pacijenta. Prema tome, ekonomski učinkovitu soluciju valja tražiti u skladnom sudjelovanju cjelovitog kompleksa sistemskih mjera u zdravstvu i odštetnom pravu, a sa ciljem smanjenja ukupnog društvenog troška na ime šteta uslijed liječničke pogreške uz istodobno održanje općeg medicinskog standarda u obavljanju zdravstvene usluge.

Ključne riječi: ekonomski učinkovita zdravstvena skrb, odgovornost za liječničku pogrešku, optimalan profesionalni standard zdravstvene skrbi, trošak štete, medicinski standard liječnika

\section{UVOD}

\subsection{Uvodne napomene}

Tematika ekonomski učinkovite zdravstvene skrbi u kontekstu liječničke pogreške nameće se kao višestruko važna tema, kako sa aspekta zaštite prava pacijenata na način da im se in praxis osigura pravo na zdravstvenu uslugu koja ne odstupa od utvrđenih standarda medicinske profesije u Hrvatskoj i EU, tako i sa ekonomskog kuta anticipirajući trendove u EU koji upućuju na realno bitno povećanje odštetnih troškova na teret hrvatskog zdravstvenog sustava u skorijoj budućnost uvjetovano fenomenologijom liječničkih pogreški, odnosno, uslijed povrede medicinskog standarda.

Polazišna hipoteza rada počinje od definicije tzv. optimalnog profesionalnog standarda zdravstvene skrbi pod čime se podrazumijeva utvrđena razina zdravstvene skrbi koja in ultima linea vodi smanjenju ukupnih društvenih troškova koji rezultiraju povredom medicinskog standarda postupanja, kao i konkretnom štetom koju trpi oštećenik u pojedinom slučaju (Shavell, 1987, str. 7). U radu se iznosi hipoteza kako učinkovita implementacija pravila građanskopravne odgovornosti zbog povrede medicinskog standarda, koja djeluju ex post u uvjetima nastale štete, redovito uzrokuje adekvatnu reakciju liječnika i drugog medicinskog osoblja već ex ante u smjeru primjene zahtijevanog stupnja dužne profesionalne pažnje u aplikaciji odnosnog dijagnostičkog/terapeutskog postupka. Provedeno istraživanje ukazuje da, prema ekonomskom modelu koji se nastavno eksplicira, odštetnopravni sustav djeluje u funkciji utvrđenja ekonomski učinkovite solucije na način da se temeljni ratio instituta građanskopravne odgovornosti ostvaruje $u$ dvostrukom smislu - (1) u vidu smanjenju troškova ostvarenog štetnog događaja 
(troškovi štete), te (2) u smanjenju troškova koji nastaju u procesu prevencije štete (troškovi medicinske prevencije).

U radu se postavlja sporedna hipoteza prema kojoj rezultati primjene instituta građanskopravne odgovornosti u Hrvatskoj, prema različitim ekonomsko-financijskim kategorijama, u bitnome odstupaju od ukupnih ekonomskih učinaka koji se ostvaruju u zemljama obuhvaćeni ovim radom. Navedena diferencijacija je posljedica smanjene učestalosti utuženja spornih slučajeva liječničkih pogreški, kao i nižeg prosječnog iznosa odštetnine, a što in ultima linea dovodi do komparativno nižeg ukupnog društvenog troška.

Središnje istraživačko pitanje kojim se rad bavi jest problematika ekonomski učinkovite zdravstvene skrbi u kontekstu građanskopravne odgovornosti za liječničku pogrešku imajući u vidu ispunjenje dva komplementarna i u dobroj mjeri podudarna cilja. Prvenstveni cilj, dakako, predstavlja ostvarenje imperativa zaštite pacijentovih prava, što implicira pružanje medicinskog tretmana sukladno lex artis, dok se sporedni i akcesorni cilj očituje u zahtjevu za minimiziranjem budućih troškova na ime eventualnih šteta u odštetnom postupku zbog liječničke pogreške, kao i u ukupnom društvenom trošku, a što se postiže kontinuiranim i racionalnim financijskim ulaganjima radi održanja ekonomski učinkovite, tj., optimalne razine zdravstvene skrbi. Ekonomska i pravna teorija su jednoglasne u ocjeni da pridržavanje pravila dužne pažnje od strane liječnika ima povoljne ekonomske učinke i to u mjeri u kojoj pravni sustav jasno određuje pravno zahtijevanu razinu skrbi (pravni standard dužne pažnje liječnika) kao adekvatnu ekonomski definiranom modelu optimalne zdravstvene skrbi. Pitanje ekonomski učinkovite zdravstvene skrbi u relaciji sa profesionalnim postupanjem liječnika, u ovome radu razmatra se kroz prizmu ponašanja liječnika u okviru medicinskog tretmana in abstracto pri čemu mjerilo ponašanja neće biti neka prosječno pametna i pažljiva osoba, nego uobičajeno pažljiv doktor. Dakle, zahtijevani prosječan standard neće biti prosječan standard građanina, nego prosječan standard koji vrijedi za liječnike - bonus pater familias standard (Faure, 2004, str. 19). Svakako valja napomenuti kako je suvremena medicina bitno doprinijela kako procesu ekonomizacije medicine u nastojanju da uspostavi optimalni standard medicinske skrbi, tako i juridizaciji medicine, napose sa aspekta pravnog nadzora nad obavljanjem zdravstvene djelatnosti.

Cilj rada je potvrđivanje gore iznesenih hipoteza pri čemu se posebno analiziraju ekonomski učinci primjene instituta građanskopravne odgovornosti zbog povrede medicinskog standarda, a napose financijski aspekt u svom totalitetu (trošak odštete, medicinske prevencije, ukupni društveni trošak), te se izlažu recentni ekonomski modeli. U ostvarenju cilja ovog rada istražene u bitne sastavnice povrede medicinskog standarda postupanja liječnika iz kuta ekonomske i pravne znanosti te su ustanovljeni zajednički kohezivni elementi koji sinergijski te uzajamno stvaraju odgovarajući ekonomsko-financijski i pravni učinak. 
Tako je rad strukturiran na način da su analizirani ekonomski učinci primjene instituta građanskopravne odgovornosti zbog povrede medicinskog standarda te su inter alia izloženi diferentni ekonomski modeli koji se bave pitanjem učinkovitog pružanja zdravstvene usluge, a sa posebnim naglaskom na hrvatski narativ. Poseban naglasak je na stavljen na pitanje utvrđenja ekonomskog standarda optimalne zdravstvene skrbi te je na projekcija financijskih svih učinaka u uvjetima djelatnog odštetnopravnog sustava koji naknađuje štete uzrokovane liječničkom pogreškom u okviru usporednog prikaza financijskih učinaka liječničkih pogreški (Hrvatska, SAD, Italija). Dakle, sukladno strukturi istraživanja, u narednim poglavljima su obrađena neka značajnija ekonomska promišljanja američkih i europskih znanstvenika usmjerena na raščlambu i definiciju funkcije odštetnopravnog sustava, a u kontekstu pronalaženja modela ekonomski učinkovite zdravstvene skrbi - optimalnog standarda medicinske skrbi. Znanstvena determinacija pojedinih teorijskih koncepata polazi od jedinstvenog stajališta ekonomske teorije da ekonomski učinkovitu soluciju valja tražiti u skladnom sudjelovanju cjelovitog kompleksa sistemskih mjera u zdravstvu i odštetnom pravu, a sa ciljem smanjenja ukupnog društvenog troška na ime šteta uslijed liječničke pogreške, naravno, uz istodobno održanje općeg medicinskog standarda u obavljanju zdravstvene usluge, što predstavlja legitimni javni i privatni interes.

Znanstvenoistraživačke metode primijenjene u ovome znanstvenom radu jesu komparativna i induktivna metoda. Iznesen je usporedni prikaz različitih teoretskih modela koji razmatraju problematiku optimalnog profesionalnog standarda zdravstvene skrbi sa posebnim osvrtom na ekonomsku analizu nobelovca Ronalda Coasea - Coaseov teorem, kao i progresivna razmišljanja profesora Richarda Epsteina koji postavlja novu paradigmu. Induktivna metoda je aplicirana tako što su zasebno analizirani pojedini ekonomski modeli te su istaknute divergencije, kao i koherentni elementi iz čega su izvedeni odgovarajući zaključci. Nadalje, u dijelu metodologije ekonomskih istraživanja provedena je komparacija financijskih učinaka odštetnopravne odgovornosti zbog povrede medicinskog standarda postupanja koja je obuhvatila SAD, Italiju i Hrvatsku.

\subsection{Pregled dosadašnjih istraživanja}

Pregled dosadašnjih istraživanja iz područja ekonomskih znanosti ukazuje na nezavidno visok stupanj znanstveno-istraživačke insuficijencije. Naime, u potpunosti izostaju relevantna istraživanja iz područja poslovnog upravljanja zdravstvenim sustavima i financija. Tako u Hrvatskoj do danas nije provedeno niti jedno istraživanje na temu ekonomski učinkovite zdravstvene skrbi povezano sa feno- 
menom liječničkih pogreški, pa čak niti niti najsumarnija analiza svih financijskih izdataka po osnovi pravomoćno okončanih odštetnopravnih postupaka zbog liječničke pogreške, a koji nedvojbeno opterećuju proračun zdravstvenih ustanova. Zatečena situacija ne bi trebala čuditi ako uzmemo u obzir da HZZO na poziciji rashoda uopće ne predviđa stavku pod kojom bi se supsumirali navedeni financijski izdaci, a što ukazuje na stanoviti upravljački nemar u istraživanom segmentu kao i evidentan izostanak politike prevencije šteta. Za ilustraciju, recentni podaci govore o kumulativnom iznosu od orijentaciono 61 milijun kuna odštetnina na teret javnih zdravstvenih ustanova koje je u razdoblju od 2012 - 2016 g. isplaćeno pacijentima ili njihovim obiteljima na osnovi utvrđene građanskopravne odgovornosti za liječničku pogrešku (Hrvatska liječnička komora, 2018). Kao opća indikacija stanja, za potrebe ovog istraživanja koristila je usporedna analiza kvalitete zdravstvene zaštite u Hrvatskoj i drugim zemljama EU (EHCI indeks) provedena od strane Ekonomskog Instituta, Zagreb i UNODC-a (2010.g.) (Budak, 2014) i to u dijelu rezultata koji se tiču kategorije poštivanja prava $i$ informiranosti pacijenata jer se posredno dotiču domene potencijalne građanskopravne odgovornosti. U svakom slučaju u Hrvatskoj u posljednje vrijeme jača potreba za cjelovitom, konzistentnom analizom svih ekonomskih i pravnih aspekata koji se tiču pružanja zdravstvenih usluga, a napose građanskopravne zaštite prava pacijenata. Valja, ipak, istaknuti da kad je u pitanju navedena tematika, te prateći ekonomski učinci odštetnopravnih postupaka, hrvatsku znanstvenu zbilju još uvijek karakterizira posvemašnji nedostatak relevantnih istraživanja i statistike. Stvarni broj aktivnih parničnih postupaka, kao i frekvencija utuženja uslijed povrede medicinskog standarda, a u odnosu na ukupan obujam korištenih zdravstvenih usluga ostaje nepoznanica. Fenomenologija liječničkih pogreški još uvijek nije kolektivno legitimirana kao bitna tema, a razloge tomu valja prvenstveno tražiti u poljima sociologije, socijalne antropologije i psihologije.

Za razliku od domaćih prilika, inozemna literatura upućuje na trend "jačanja sklonosti traženja odštete", a na području SAD i EU (napose u nekim zemljama poput Italije), već se može govoriti o lukrativnoj industriji liječničke odgovornosti koja u SAD producira kumulativni godišnji izdatak po različitim osnovama od \$17 - 29 milijardi godišnje, prema američkom Institute of Medicine. Navodi se da su posljedice od liječničkih pogreški u SAD pretekle čak i štete izazvane prometnim nezgodama te godišnje oštećuju više od 1,5 milijuna američkih pacijenata (Arlen, 2010, 2013). U Velikoj Britaniji se bilježi značajan porast odštetnopravnih postupaka kojih je 1978.g. bilo tek otprilike 500 u odnosu na čak 7000 u razdoblju 1990 - 1991.g. sa daljnjim rastućim trendovima u današnje vrijeme (Tarantino, Giai Via, Macri, Eramo, Marino i Marsella, 2013, str. 6), napose kad je u pitanju Italija, te se izvještava o 50\% povećanju broja parnica radi popravljanja štete zbog liječničke pogreške u vremenu između 1980 - 1986 sa evidentiranim dodatnim porastom od 90\% u 1987 (Traina, 2008), dok se godišnje pokreće cca. novih 15.000 civilnih po- 
stupaka radi naknade šteta uzrokovanih liječničkom pogreškom, pri čemu zdravstvene ustanove na ime odštetnine isplaćuju iznos od cca. EUR 10 milijardi per anno (Traina, 2008, str. 1). Bogata sudska praksa na području SAD i ekonomski razvijenijih članica EU dala je odgovarajući impuls znanstvenim istraživanjima, kako na poljuekonomije, tako i prava.

Europski podaci, uglavnom iz država članica Europske unije, kontinuirano pokazuju da se liječničke pogreške i štetni događaji povezani sa zdravstvenom zaštitom ozbiljuju u $8 \%$ do $12 \%$ hospitalizacija. Tako se infekcije uzrokovane nestručnom zdravstvenom skrbi svake godine pojavljuju u prosjeku na 1 od 20 bolesnika u bolnici (procijenjeno na 4,1 milijuna pacijenata), pri čemu su četiri najčešće vrste: infekcije mokraćnog sustava (27\%), infekcije donjih dišnih puteva (24\%), kirurške infekcije na mjestu (17\%) i infekcije krvotoka (10,5\%), dok je multirezistentni stafilokokni aureus (MRSA) izoliran u oko 5\% svih infekcija povezanih sa zdravstvenom skrbi. Dok 23\% građana Europske unije tvrdi da ih je medicinska greška izravno pogodila, $18 \%$ smatra da su pretrpjeli ozbiljnu liječničku pogrešku u bolnici, a $11 \%$ navodi da im je propisan pogrešan lijek. Dokazani slučajevi liječničkih pogreški pokazuju da se $50 \%$ do $70,2 \%$ tako nastale štete može spriječiti sveobuhvatnim sustavnim pristupom u smjeru sigurnosti pacijenata. Statistički podaci ukazuju da bi strategije za smanjenje stope štetnih događaja od nestručnog medicinskog tretmana samo u Europskoj uniji dovele do sprečavanja više od 750000 štetnih liječničkih pogrešaka godišnje, što bi za poljedicu imalo više od 3,2 milijuna manje dana hospitalizacije, 260000 manje slučajeva štete u vidu trajnog invaliditeta i čak 95000 manje smrti godišnje. (Word Health Organisation,.

\section{EKONOMSKA ANALIZA UČINAKA PRIMJENE INSTITUTA GRAĐANSKOPRAVNE ODGOVORNOSTI ZBOG POVREDE MEDICINSKOG STANDARDA}

\subsection{Ekonomski ogled na odštetnopravnu problematiku liječničkih pogreški}

Kako je prethodno eksplicirano medicina nije u potpunosti egzaktna znanost tako da obavljanje zdravstvene djelatnosti uvijek sa sobom nosi određeni rizik koji se može ispoljiti u nastupu štetnih, neželjenih posljedica medicinskog tretmana, bilo da se radi o štetnom postupanju koje predstavlja liječničku pogrešku ili se pak radi o povredi pacijentova prava na suodlučivanje (informirani pristanak). Svojedobno istraživanje u dvije zdravstvene ustanove u SAD-u (1999. g.), pokazalo je da 
čak 2,9\%, odnosno 3,9\% bolesnika trpi povredu zdravlja što je u kauzalnoj vezi sa provedenim medicinskim tretmanom, dok u Danskoj taj postotak iznosi visokih 9\%, u Francuskoj 8,9\%, a u Velikoj Britaniji 11. Posebno je ilustrativan podatak da su posljedice liječničkih pogreški osmi uzrok smrti u SAD-u (Škavić i Zečević, 2008, str. 23).

Ekonomski diskurs u odnosu na analiziranu problematiku naglašava ekonomske učinke primjene pravnog instituta građanskopravne odgovornosti za štetu u segmentu rashoda koji se pojavljuju na stani prevencije nastupa štetnih događaja, kao i na ime naknade tako nastalih šteta. Ekonomisti suglasno ističu kako odštetnopravni sustav valja smatrati poticajnim u smislu kontinuiranog poboljšanja zdravstvene skrbi. Ideja da potencijalni štetnik treba obeštetiti svoju žrtvu (oštećenika) trebala bi imati preventivni učinak (Schiemann, 1981, str. 185). Na taj način, također, naglašavaju se najbolji modaliteti u zaštiti prava pacijenata kao potencijalnih oštećenika te se utječe na sprječavanje pojave tkz. viktimizacije, jer nitko ne može osporiti da je prevencija štete također način zaštite žrtava. U tom razlikovanju ujedno je sadržan ex ante i ex post pristup. Iako je pravni sustav uglavnom usmjeren djelovanju ex post, već kad je došlo do štetnog događaja koji zahtijeva popravljanje štete, ekonomisti pitanju obeštećenja pristupaju ex ante. U tom smislu, ekonomska teorija postavlja pitanje kako bi pristup ex post mogao povratno poticajno utjecati na način da pro futuro preventivno djeluje. Jedan od prvih koji je sustavno pristupio razradi tog problema bio je odvjetnik Guido Calabresi sa pravnog odsjeka na Sveučilištu Yale. U njegovom poznatom djelu „Troškovi nezgode" (The Costs of Accidents) Calabresi razlikuje primarne, sekundarne i tercijarne troškove. Primarni troškovi od nezgode nastaju izbjegavanjem nastanka štete koja bi se uopće mogla pojaviti; sekundarni troškovi odnose se na ravnomjerno raspoređivanje financijskih gubitaka, dok se tercijarni troškovi odnose na rashode administracije u okviru određenog pravnog sustavu u relaciji sa postupkom naknade štete. Iznosi se kako bi odštetnopravni sustav u svom totalitetu trebao dati poticaj da se umanji totalni društveni trošak uslijed nezgoda, donosno, trebalo bi kreirati pravno-ekonomski sustav koji bi trebao minimalizirati ukupni trošak koji stoji u kauzalnoj vezi sa nastupom štetnih događaja (nezgoda) (Faure, 2004, str. 7).

U ekonomskoj teoriji se postavilo pitanje na koji način liječnici i zdravstvene ustanove mogu optimalno zaštititi prava pacijenata i kakva pravila profesionalne civilnopravne odgovornosti valja u tom smislu primijeniti. Odgovor na pitanje upućuje prvenstveno na klasični model nezgoda (̌̌teta) koji preispituje ulogu odštetnog prava i profesionalne odgovornosti te ga dovodi u vezu sa ukupnim društvenim boljitkom koji ovisi o tome koliko je svaki pojedini pružatelj zdravstvene usluge (liječnik) uložio u medicinsku obradu svakog pojedinog pacijenta. Koncept klasičnog modela nezgoda (̌̌teta) implicira da građanskopravna odgovornost koja nastaje iz povrede medicinskog standarda osnažuje opću društvenu korist jer bi u 
nedostatku takve pravne odgovornosti, zdravstvene ustanove i liječnici, prirodno težili smanjenju vlastitih financijskih ulaganja na ime troškova medicinskog tretmana, a što bi posljedično dovelo do pada očekivane razine zdravstvene usluge koju su obvezni pružiti (Arlen, 2013, str. 34). U kontekstu odgovornosti za liječniku pogrešku, istražuje se individualna odluka pružatelja zdravstvene ustanove koja se tiče ulaganja u konkretan medicinski tretman te koja indicira selektirani stupanj intenziteta medicinskog tretmana in specie, kao i specifični učinak takvog tretmana na određenog pacijenta. Model podrazumijeva situaciju prema kojoj trošak obavljanja odabranog medicinskog tretmana pada na teret pružatelja zdravstvene usluge kojemu su za razliku od pacijenta poznata pravila medicinske struke koja omogućuju pružanje optimalne profesionalne usluge. Može se realno predmnijevati da bi u nedostatku sustava odštetnopravne odgovornosti kao svojevrsnog poticaja, bilo sasvim razumno za očekivati da bi liječnici u značajnoj mjeri provodili tek suboptimalni medicinski tretman koji ne odgovara zahtijevanom medicinskom standardu, budući u cijelosti i samostalno snose trošak liječenja, dok istodobno ne ostvaruju maksimalnu ekonomsku korist od ulaganja u spomenuti optimalan medicinski tretman. Međutim, navedena anomalija može se učinkovito otkloniti interpolacijom sustava zdravstvenog osiguranja jer u tom slučaju trošak zdravstvene usluge prelazi sa liječnika na osiguratelja (Danzon, 1997). Valja uočiti određenu insuficijenciju izloženog teorijskog modela. Naime, očito je kako tradicionalna analiza polazi od situacija kada do povrede medicinskog standarda dolazi svjesno i voljno od strane pružatelja zdravstvene usluge, a radi ostvarenja vlastitih financijskih ušteda, dok istodobno analiza potpuno zanemaruje one uobičajene i učestale slučajeve liječničkih pogreški kad je aplicirani suboptimalni medicinski tretman rezultat isključivo nepažnje liječnika bez voljnog momenta. Ističe se gledište kako se preventivno smanjenje frekvencije liječničkih pogreški može postići permanentnim ulaganjem u sigurnost pacijenta (Arlen, 2013, str. 39), dakle ex ante, koje uključuje stalno stručno usavršavanje, ulaganje u suvremenu medicinsku tehnologiju i sl., a čime bi se ultimativno utjecalo na prosječno viši stupanj primijenjenog standarda medicinske usluge. Na taj način bi se u bitnome umanjio opći rizik od pojave nestručnog medicinskog tretmana sa pratećim štetnim posljedicama zdravstvenim, ekonomskim, pravnim, dok bi specifični rizik provođenja tretmana u odnosu na određenog pacijenta i dalje postojao. U slučaju ostvarenja takvog specifičnog rizika uslijed poduzimanja medicinskog tretmana koji nema obilježje in optima forma et bonus pater familias, slučaj bi se dalje pravno i ekonomski rješavao sukladno pravilima pravnog instituta građanskopravne odgovornosti. 
H. VOJKOVIĆ: Ekonomski učinkovita zdravstvena skrb i liječnička pogreška

\subsection{EKONOMSKI STANDARD OPTIMALNE ZDRAVSTVENE SKRBI}

Ekonomski teoretičari posebno razmatraju problematiku optimalnog profesionalnog standarda zdravstvene skrbi te pri tom koriste klasičnu cost/benefit analizu kako bi se odredila ona konkretna razina zdravstvene skrbi koja ultimativno vodi do minimiziranja ukupnih društvenih troškova koji rezultiraju povredom medicinskog standarda postupanja i korelativnom štetom koju oštećenik trpi kao posljedicu (Shavell, 1987, str. 7). Navodi se gledište da bi već sama mogućnost primjene pravila građanskopravne odgovornosti, koja djeluju ex post u uvjetima nastale štete, trebala izazvati adekvatnu reakciju subjekata već ex ante kako bi se primijenila odgovarajuća profesionalna pozornost ili korigirale aktivnosti u smjeru smanjenja rizika od nastupa štetnog događaja. Prema izloženom ekonomskom modelu odštetnopravni sustav je u funkciji utvrđenja ekonomski učinkovite solucije jer temeljni ratio instituta građanskopravne odgovornosti vide $\mathrm{s}$ jedne strane, $\mathrm{u}$ smanjenju troškova ostvarenog štetnog događaja - troškovi štete, te s druge strane u smanjenju troškova koji nastaju u procesu prevencije štete - preventivni troškovi (Calabresi, 1970, str. 17). Kako iznosi Michael Faure ukupan društveni trošak štete može se izračunati sljedećom formulom:

$$
C=p(x, y) L+A(x)+B(y)
$$

pri čemu je

C = ukupni društveni trošak - zbroj potencijalne štete i trošak skrbi

A = oštećenik (̌̌rtva)

B $=$ štetnik

$\mathrm{x}=$ razina skrbi za oštećenika (pacijent)

y = razina skrbi koju je primijenio štetnik (liječnik)

$p=$ vjerojatnost nastanka štetnog događaja

$\mathbf{L}=$ volumen štete

Pretpostavlja se da su obje strane neutralne s obzirom na rizik, te da je volumen štete (L) neovisan od razine skrbi, odnosno da će pojačana skrb smanjiti vjerojatnost nastanka štetnog događaja (p), te da isključivo oštećenik trpi štetu (A) kao posljedici štetnog događaja. Kako bi se minimaliziralo društveni trošak (C), razina skrbi mora se postavit na način da je $\mathbf{x}=\mathbf{x}^{*}$ za oštećenika, odnosno $\mathbf{y}=\mathbf{y}^{*}$ za štetnika. U konačnom zbroju, granična razina koristi od povećanja skrbi jednaka je graničnom trošku po osnovi povećane skrbi, pri čemu sa ekonomskog stanovišta optimalna skrb stoga nije jednaka najvećoj mogućoj razini skrbi koja bi eventualno mogla biti pružena. Najveća bi razina skrbi mogla dovesti do ekonom- 
skog rasapa sustava jer bi očekivani granični troškovi mogli bili bi veći od graničnih koristi u smanjenju rizika od nastanka štete. Dakle, problem je bio u tome da se utvrdi odgovarajuća razina skrbi, kako za $\mathbf{x}^{*}$ tako i za $\mathbf{y}^{*}$ (Faure, 2004, str. 9).

Kad ne bi postojala pravila građanskopravne odgovornosti, štetnik ne bi imao ekonomsko-pravni poticaj postupati sa dužnom profesionalnom pozornosti budući da uzrokovanje štete ne bi pogađalo njegovu ekonomsku sferu. U tom smislu, ekonomska teorija je ustanovila pravila dužne pažnje (neglicence rule) kao pravnoekonomski institut koji izravno potiče potencijalnog štetnika da se pridržava pravila struke u primjeni odgovarajućeg profesionalnog standarda postupanja sa ciljem ostvarenja učinkovite razine dužne skrbi. Implementacija pravila dužne pažnje, kako ih pojmovno određuje ekonomska znanost, odnosno, odštetnopravni sustav sa svojim pravnim i ekonomskim implikacijama, posljedično dovode do toga da potencijalni štetnik pruža uslugu u režimu standarda optimalne skrbi jer pravni sustav profesionalni standard medicinskog postupanja izjednačuje upravo sa ekonomskom konstrukcijom optimalne skrbi za primatelja usluge - hipotetičkog oštećenika (Calabresi, 1975, str. 658; Shavell, 1987). U ovom kontekst valja napomenuti da je hrvatski pravni sustav u cijelosti sukaladan sa gore iznesenim modelom, te se od liječnika se očekuje da pri obavljanju medicinske usluge postupa s pažnjom dobrog stručnjaka, odnosno da postupa s povećanom pažnjom, prema pravilima struke i običajima profesije (ZOO, čl. 18 st. 2).Naime, hrvatsko pozitivno pravo od medicinskog djelatnika traži da postupa prema standardu dobrog, a ne tek prosječnog stručnjaka, a povredu tako nametnutog profesionalnog standarda određuje kao štetnu radnju s obilježjem protupravnosti u subjektivnom smislu, naravno, uz pretpostavku nastanka pravno relevantne štete. Liječnicima se izrijekom nameće obveza da u provođenju medicinskog tretmana postupaju prema pravilima zdravstvene struke, tako da svojim postupcima ne ugroze život i zdravlje ljudi (Zakon o zdravstvenoj zaštiti, čl. 124 st. 3) te da promiču dostojanstveno i odgovorno profesionalno ponašanje poštivanjem propisa, pravila struke i kodeksa medicinske etike i deontologije (Zakon o liječništvu, NN 121/03, 117/08, čl. 2 st. 2 t. 5).

S obzirom da je optimalan standard zdravstvene skrbi određen kao takva razina skrbi gdje su granični troškovi skrbi jednaki graničnim koristima po osnovi smanjenja rizika od nastanka štete, nepridržavanje ovako determiniranog standarda optimalne skrbi neće biti od ekonomskog interesa za potencijalnog štetnika, jer bi u neželjenoj situaciji ostvarenja rizika od nastanka štete povećao svoje ukupne troškove. Na taj način primjena pravila dužne pažnje u praksi imala bi povoljne ekonomske učinke. Naravno, sve dok pravni sustav jasno određuje pravno zahtijevanu razinu skrbi (pravni standard dužne pažnje liječnika) kao adekvatnu ekonomski definiranom modelu optimalne zdravstvene skrbi. Izloženi ekonomski model koji se zasniva na standardu optimalne skrbi koji istodobno odgovara relevantnom pravnom standardu može se definirati na sljedeći način (Faure, 2004, str. 11): 
Ako pretpostavimo da je razina određene skrbi ista u pravnom sustavu kao $i$ ona u modelu optimalne razine skrbi $\left(y^{*}\right)$, tada je razumno za očekivati da će štetnik slijediti optimalni standard skrbi budući je to za njega ekonomski najjeftinije rješenje. Ako štetnik troši manje od $\boldsymbol{y}^{*}$ za skrb, njegov će ukupan trošak za skrb iznositi prema sljedećoj formuli:

$$
\text { p }(\mathbf{o , y o}) L+B(\text { yo })
$$

S druge strane ako primjenjuje efikasnu razinu skrbi koja proizlazi iz optimalnog standarda tada neće morati pokrivati troškove mogućeg gubitka jer su u tom slučaju jedini troškovi koje štetnik podmiruje - troškovi efikasne, optimalne skrbi: B ( $\left.\mathbf{y}^{*}\right)$. Odgovor na pitanje hoće li u hipotetičkom slučaju B postupati sukladno standardu optimalne skrbi koji omogućuje učinkovitu zaštitu interesa potencijalnog oštećenika efikasnu skrb, ovisit će o sljedećim parametrima:

$$
\text { p }(\mathbf{o , y o}) \mathbf{L}+\mathbf{B}(\mathbf{y o})><\text { B }\left(\text { y }^{*}\right)
$$

Naime, ako je zbroj očekivanih gubitaka i realnih troškovi na ime pružene profesionalne skrbi viši od troškova efikasne, optimalne skrbi, tada realno za očekivati da će potencijalni štetnik aplicirati standard optimalne skrbi jer mu je to evidentno u ekonomskom interesu. No s druge strane, ako su navedeni troškovi niži od cijene optimalne skrbi, za štetnika će bit jeftinije da ne primjenjuje standard optimalne skrbi. Kako je varijabla $\mathbf{y}^{*}$ definirana kao točka na kojoj je razina društvenih troškova najniža, tada će $\mathbf{p}(\mathbf{0}, \mathbf{y o}) \mathbf{L}+\mathbf{B}(\mathbf{y o})$ uvijek biti viša od troškova uzimanja $\mathbf{y}^{*}$ skrbi. Slijedom toga možemo zaključiti da su troškovi $\mathbf{y}^{*}$ na ime ostvarenja učinkovite optimalne skrbi ekonomski privlačniji za štetnika jer na taj način ostvaruje ekonomski povoljniju računicu, sve dok odštetnopravni sustav određuje $\mathbf{y}^{*}$ kao relevantan pravni standard razine skrbi (Calabresi, 1975, str. 14; Shavell, 1987).

Ekonomska analiza nobelovca Ronalda Coasea naglašava kako učinkovitost alokacije resursa uvijek postoji, bez obzira na pravila odštetnog prava, sve dok su troškovi transakcija na nuli. Coaseov teorem simulira hipotetičku situaciju u kojoj su stranke u cijelosti informirane tako da pravila odštetnopravne odgovornosti nemaju učinka na poduzimanje preventivnih mjera. Karakterističan primjer možemo uočiti u slučaju odgovornosti za proizvod/uslugu gdje su proizvođač i kupac (potencijalni štetnik i oštećenik) međusobno povezani mehanizmom cijena pri čemu ostvarene cijene indiciraju raspodjelu rizika od nastupanja štetnih posljedica koje bi bile u uzročnoj vezi sa konzumacijom proizvoda ili usluge. Sukladno postavkama navedenog teorema, kada su subjekti u cijelosti informirani o mogućim rizicima, promjena u režimu odgovornosti neće utjecati na preventivne mjere. Ako proizvođač nije odgovoran za prouzrokovanu štetu, per exemplum, nekog farma- 
ceutskog proizvoda, to je zato jer kupac u svakom slučaju pridodaje očekivani gubitak (rizik) na tržišnu cijenu proizvoda te samo na taj način kupuje proizvod po punoj cijeni (koja obuhvaća i navedeni rizik) (Calabresi, 1986; Hamada, 1976). U kontekstu obavljanja zdravstvenih usluga, činjenica pravne zaštite oštećenika u okviru sustava normi ugovorne ili deliktne odgovornosti, značajna je sa ekonomskog gledišta, čak i u slučaju kada oštećenik- pacijent nije bio primjereno informiran. Coeseov teorem naglašava da takva pravna zaštita često ima ograničen učinak u strogo ekonomskom smislu. Naime, uzimajući u obzir da činjenicu da pružatelj zdravstvene skrbi ima mogućnost «prenijeti» na pacijenta trošak povećanje zaštite potrošača (pacijenta) posredstvom mehanizma cijena, može se pretpostaviti da će proizvođač povisiti cijenu pod izlikom da on sada snosi rizika od nastupa štetnog događaja te korelativnu obvezu popravljanja štete. Na taj način potrošač de facto plaća za povećanu zaštitu koja mu je na taj način omogućena. U ekonomskoj teoriji se upućuje na revolucionarni prijedlog čuvenog profesora iz Chicaga Richarda Epsteina. Njegova središnja zamisao je da bi liječnici i bolnice trebali pregovarati ex ante na okolnost volumena zdravstvene skrbi, očekivanog budućeg troška zdravstvene skrbi koja bi trebala biti pružena, te formule raspodjele rizika od štetnog događaja, a koju bi zatim prihvatio osiguravatelj na temelju izdane police zdravstvenog osiguranja koja uključuje adekvatni premijski rizik (Epstein, 1976).

Općenito se može ustvrditi da u onim zdravstvenim sustavima gdje su pružatelji zdravstvene skrbi slobodni samostalno oblikovati cijenu zdravstvenih usluga, svako proširenje odgovornosti zbog eventualne povrede medicinskog standarda dovodi do povećanja premije osiguranja koje se in ultima linea ekonomski prevaljuje na pacijente u vidu povećanih troškova zdravstvenog osiguranja. Nasuprot tome, u sustavima javnog zdravstva s reguliranim cijenama, proširenje odgovornosti može dovesti ili do viših troškova po javni osiguravateljni sustav čime se troškovi posredno povećavaju za porezne obveznike ili može doći do povećanja ekonomske izloženosti štetnika s obzirom da štetu naknađuje izravno iz vlastite ekonomske mase bez interpolacije osiguratelja.

\subsection{KOMPARATIVNI PRIKAZ FINANCIJSKIH UČINAKA LIJEČNIČKIH POGREŠKI (SAD, ITALIJA, HRVATSKA)}

\subsubsection{SAD}

U ekonomskoj, medicinskoj i pravnoj literaturi koja je poslužila za potrebe analize opetovano se ističe naglašeni trend iniciranja odštetnopravnih postupaka na ime naknade štete koja je uzrokovana povredom medicinskog standarda po- 
stupanja liječnika. Tako se navode podaci za SAD koji ukazuju na porast ukupnih troškova koji nastaju u uzročno-posljedičnoj vezi sa liječničkom pogreškom. Bilježi se porast troškova odvjetničkog zastupanja koji iznosi prosječno po slučaju \$ 47.158,00 u 2010.g. što je porast od 62,7\% od 2001.g.; tijekom 2010.g. čak $63,7 \%$ odštetnopravnih postupaka je pravomoćno okončano u korist tuženih liječnika/zdravstvenih ustanova pri čemu su troškovi odvjetnika branitelja iznosili u prosjeku \$26.851,00; prosječni ostvareni odštetnopravni zahtjev iznosi u 2010.g. \$331.947,00 što predstavlja povećanje od 11,5\% od 2001.g.; udio polica osiguranja od profesionalne odgovornosti liječnika koje prekoračuju limit po štetnom događaju od \$1 milijun povećao se sa $28 \%$ na $41 \%$ u istom razdoblju (Lewis, 2012). Nadalje, u američkoj ekonomskoj teoriji (Arlen, 2013) se ističe kako između 4-18\% pacijenata trpe posljedice liječničke nepažnje u obavljanju medicinskog tretmana sa brojnim štetnim posljedicama na zdravlje i ekonomsku sferu pacijenata. Neovisno o tome u pravilu tek manji broj slučajeva koji imaju obilježja liječničke pogreške biva predmetom građanskopravnog postupka za naknadu štete. Ipak, prema jednom istraživanju, financijski izdaci uvjetovani postupanjem liječnika contra legem artis izravno dovode do povećanja bolničkih rashoda u rasponu od \$1.246,00 do 4.769,00 godišnje, ovisno o tipu zdravstvene ustanove i specifičnom medicinskom tretmanu koje se tamo provodi. Sve u svemu, ukupni godišnji izdaci po različitim osnovama, a koji su per directum et indirectum izazvani postupanjem liječnika i drugog zdravstvenog osoblja protivnom pravilima medicinske struke procjenjuju se na vrtoglavih \$17 - 29 milijardi godišnje, prema američkom Institute of Medicine (Arlen, 2013).

\subsubsection{Italija}

Slična je situacija u Italiji. Prema dostupnim podacima (Traina, 2008, str. 1), na godišnjoj razini pokreće se otprilike 15.000 odštetnopravnih postupaka uslijed šteta uzrokovanih liječničkom pogreškom, a zdravstvene ustanove na ime odštetnine pacijentima isplaćuju ikumulativni iznos od cca. EUR 10 milijardi. Relativno najveći postotak tužbenih zahtjeva tiče se liječničkih pogreški u okviru ortopedijske kirurgije i traumatologije, a bilježi se i relativno najveći broj pokrenutih kaznenih postupaka protiv liječnika i drugog zdravstvenog osoblja na cijelom području EU. Referentna statistika ukazuju da liječnik sa 20 godina prakse ima $80 \%$ šansi da će protiv njega biti pokrenut građanskopravni postupak zbog povrede pravila medicinske struke uz jednaki postotak vjerojatnosti od $80 \%$ da će predmetni postupak biti okončan u njegovu korist odbijanjem tužbenog zahtjeva (Fattorini, Peretti, Bergamini i Valentini, 2007). Prema drugom talijanskom istraživanju (Tarantino i sur., 2013), građanskopravni postupak radi naknade štete pokrenut 
je u odnosu na 243 kirurga pri čemu je utvrđena odgovornost u $75 \%$ slučajeva od toga čak $61 \%$ iz područja elektivne ortopedske kirurgije; kirurški timovi su tuženi u svega 30 slučajeva te je presuđena građanskopravna odgovornost i određena naknada štete u 22 sporna slučaja; ukupno dosuđeni iznos na ime popravljanja štete iznosio je EUR 12.350.000,00. Interesantno je da u pitanju štetne posljedice sa smrtnim ishodom sudovi rade diferencijaciju između hitne i elektivne kirurgije tako da odštetu dosuđuju u prosječnom iznosu od EUR 896.989,00 kad je u pitanju elektivna kirurgija u odnosu na EUR 297.921,00 kad je smrt pacijenta uzrokovana hitnim kirurškim zahvatom (traumatologija).

\subsubsection{Hrvatska}

Nedavna usporedna analiza kvalitete zdravstvene zaštite u Hrvatskoj i drugim zemljama EU (EHCI indeks) pokazala je da neovisno o povremenim javnim kritikama sustava javnog zdravstva u Hrvatskoj, pacijenti ipak u pretežnoj mjeri iskazuju zadovoljstvo radom medicinskog osoblja. U tom smjeru ide istraživanje Ekonomskog Instituta, Zagreb i UNODC-a iz 2010. godine provedeno na 3.000 ispitanika. Istraživanje je pokazalo da oko 40 posto građana smatra da je kvaliteta usluge koju pružaju liječnici i medicinske sestre u Hrvatskoj "vrlo dobra", a dodatnih 40 posto smatra da je usluga "dobra"; 80 posto građana ocijenilo je kvalitetu medicinske usluge $u$ javnom zdravstvu dobrom i vrlo dobrom, a u istom su istraživanju zdravstveni djelatnici najbolje ocijenjeni javni djelatnici među svim javnim službama u Hrvatskoj (Budak, 2014). Za potrebe ovog znanstvenog rada posebno nas zanimaju rezultati navedenog istraživanja koji se tiču kategorije poštivanja prava i informiranosti pacijenata jer se izravno dotiču domene potencijalne građanskopravne odgovornosti. Naime, povrede određenih prava pacijenata ipso iure konstituiraju nastanak obveznopravnog odnosa odgovornosti za štetu. Primjerice, povreda pacijentovog prava na zdravstvenu uslugu prema pravilima lege artis ( $\mathrm{t} j$., prema svim pravilima medicinske struke i relevantnih medicinskih spoznaja), povreda prava na informirani pristanak, kao i svaka druga povreda drugih akcesornih subjektivnih prava pacijenta koja su u funkciji ostvarenja općeg medicinskog standarda obavljanja zdravstvene usluge. Tako povreda obveze stručnog provođenja pojedinog dijagnostičkog ili terapijskog postupka predstavlja tipičan oblik liječničke pogreške, dok se povreda prava na informirani pristanak kvalificira kao liječnička pogreška in extenso sensu (Vojković, 2013). Bez obzira na modalitete liječničke nepažnje i nestručnosti u izvođenju konkretnog medicinskog tretmana, pravne posljedice takve protupravne radnje koja je u uzročno-posljedičnoj vezi sa nastalom štetom, su identične - građanskopravna odgovornost liječnika (zdravstvene ustanove) i pravo oštećenika na popravljanje štete. 
Citiranim istraživanjem Ekonomskog Instituta koja se ticalo kategorije poštivanja prava i informiranosti pacijenata, nastojalo se ocijeniti koliko se postojeći Zakon o zdravstvenoj zaštiti (NN 150/08, 155/09, 71/10, 139/10, 22/11, 84/11, $154 / 11,12 / 12,35 / 12,70 / 12,144 / 12,82 / 13,159 / 13,22 / 14,154 / 14,70 / 16,131 / 17$ ) temelji na pravima pacijenata; uključenost udruga pacijenata u donošenje odluka; mogućnost osiguranja liječničke odgovornosti; pravo na drugo mišljenje; pristup vlastitoj medicinskoj dokumentaciji; postojanje registra licenciranih liječnika; pristup interaktivnoj web usluzi ili 24-satnom telefonu za zdravstvene informacije; financiranje zdravstvene zaštite u inozemstvu za članice EU-a; vođenje kataloga davatelja usluga rangiranih po kvaliteti; primjena elektroničkih registara pacijenata odnosno EPR rješenja (electronic patient record); online usluge pacijentima te izdavanje e-recepata. Zanimljivo je primijetiti kako je u prvoj analiziranoj kategoriji poštivanja prava i informiranosti pacijenata, koja je nosila maksimalnih 150 bodova i imala 12 pokazatelja, Hrvatska postigla rezultat od 121 boda što je 80 posto postignuća, dok su tri mjerena parametra donekle pokvarili bolji rezultat, a odnose se na pokazatelje osiguranja liječničke odgovornosti, financiranja zdravstvene zaštite u inozemstvu za ččlanice EU-a i vođenja kataloga davatelja usluga rangiranih po kvaliteti. Sa 656 osvojenih bodova Hrvatska se nalazi na 20. mjestu od ukupno 34 zemlje i nalazi se u rangu srednje skupine zemalja prema mjerilu EHCI indeksa (Vehovec, 2014, str. 290).

Hrvatski propisi iz područja zdravstva, normirajući model ostvarivanja kvalitete zdravstvene zaštite, prihvaćaju načelo učinkovitosti $i$ djelotvornosti sustava kvalitete zdravstvene zaštite i sigurnosti zdravstvenih postupaka, koje se ostvaruje provedbom mjera za osiguranje kvalitete zdravstvene zaštite (Zakon o kvaliteti zdravstvene zaštite i socijalne skrbi, čl. 4). Navedenim sustavom mjera postiže se optimalan odnos između učinaka provedenih zdravstvenih postupaka i troškova nastalih njihovom provedbom, uvažavajući pritom tehničke, organizacijske i gospodarske čimbenike. Sukladno zasadama klasičnog modela nezgoda (šteta) (Arlen, 2013, str. 34). koje je eksplicirano u ranijim poglavljima, hrvatski zdravstveni model ulogu odštetnog prava i građanskopravne strukovne odgovornosti liječnika dovodi u vezu sa ukupnim društvenim boljitkom koji ovisi o tome koliko je svaki pojedini pružatelj zdravstvene usluge (liječnik) uložio u medicinsku obradu svakog pojedinog pacijenta. Model predviđa da trošak obavljanja medicinskog tretmana pada na teret pružatelja zdravstvene usluge kojemu su za razliku od pacijenta poznata pravila medicinske profesije koja omogućuju pružanje optimalne profesionalne usluge. Dodirna točka kooperacije te interdependentia ekonomskog, pravnog i zdravstvenog sustava određena je definicijom optimalnog profesionalnog standarda zdravstvene skrbi. Naime, kako smo ranije naveli dosljedna primjena pravila dužne pažnje (neglicence rule), odnosno, odštetnopravni sustav sa svojim pravnim i ekonomskim implikacijama per consequens dovode do situacije da subjekt u poziciji mogućeg štetnika profesionalnu uslugu obavlja u režimu stan- 
darda optimalne skrbi budući da pravni sustav navedeni standard medicinskog postupanja izjednačuje sa ekonomskom kategorijom optimalne skrbi za pacijenta (Calabresi, 1975, str. 658; Shavell, 1987). Kako je optimalan standard medicinske skrbi određen razinom skrbi gdje su granični troškovi medicinske usluge jednaki graničnim koristima po osnovi smanjenja rizika od nastanka štete, voljno nepridržavanje ovako definiranog standarda optimalne skrbi neće biti od ekonomskog interesa za mogućeg štetnika jer bi u slučaju ostvarenja rizika od nastupa štetnog događaja imao dodatne neplanirane financijske izdatke. Razvidno je da implementacija prihvaćenog modela zdravstvene skrbi u okviru opisanog teoretskog modela i djelatne kohezije ekonomskih, pravnih i medicinskih sustava, rezultira povoljnim ekonomskim učincima i u varijantama ex ante i ex post, a što je elaborirano ranije. Dakako, to vrijedi po uvjetom da pravni sustav izjednačuje pravni standard dužne pažnje liječnika sa ekonomskom konstrukcijom optimalne medicinske skrbi za pacijente, sukladno načelima sigurnosti pacijenta te učinkovitosti i djelotvornosti sustava kvalitete zdravstvene zaštite i sigurnosti zdravstvenih postupaka. U tom smislu valja apostrofirati dominantno gledište ekonomske i pravne znanosti i prakse, a prema kojem jedini „zajednički nazivnik“ za utvrđivanje postojanja pogreške u medicinskom tretmanu može biti povreda dužne pažnje (Petrić, 2005, str. 123).

Kad su u pitanju financijski učinci na poslovanje zdravstvenih ustanova u $\mathrm{Hr}$ vatskoj , a koji bi bili u vezi sa odštetnopravnim postupcima koji se vode radi naknade štete uslijed liječničke pogreške u tretmanu, konzultirano je izvješće HZZO za izvještajno razdoblje siječanj-prosinac 2016, 2017, 2018 godine. Na poziciji rashoda evidentirani su ostali rashodi - naknade štete, međutim proukom izvješća utvđeno je kako se rečeni rashod odnosi na štete od profesionalnih oboljenja te da izdaci na ime naknade pacijentima po osnovi pravomoćno dosuđene odštete zbog liječničke pogreške nisu zabilježeni, pa ni u varijanti refundacije prema zdravstvenim ustanovama. Nastavno su analizirana dostupna financijska izvješčća vodećih hrvatskih kliničko-bolničkih cetara te je iz izvještaja o prihodima $i$ rashodima, primicima i izdacima za tri uzastopne godine (2016-2018), pod stavkom ostali rashodi, utvrđeno kako, primjerice, KBC Rebro kontinuirano bilježi pad troškova na ime sudskih naknada štete. Naime, navedeni troškovi su tijekom 2016 g. ostvareni u kumulativnom iznosu od 5.586.337,00 kn, (po strukturi se odnose na rashode za odštetne rente i sudske troškove u iznosu 4.335.985,00 kn te zatezne kamate po sudskim presudama u iznosu 1.250.352,00 kn), dok je tijekom $2017 \mathrm{~g}$. došlo do smanjenja promatranog rashoda na iznos od 1.959.145,00 kn sa jasnom tendencijom daljnjeg pada u narednoj godini kada je na ime naknade štete zabilježen trošak od svega $823.025,00 \mathrm{kn}$. S druge strane, KBC Firule je u isto razdoblju zabilježio drastičan porast troškova na ime naknade štete zbog liječničke pogreški. Prema dostupnim podacima ukupni rashod radi popravljanja štete fizičkim osobama i obiteljima na temelju sudskih presuda i nagodbi u vezi sa smrću bliskih osoba iznosio je za 2018 g. 1.756.368,00 kn, a što predstavlja povećanje od 
vrtoglavih 282,1\% u odnosu na prethodno poslovno razdoblje. Takva nepovoljna pojava može se uočiti u slučaju KBC Sestre Milosrdnice koji je tijekom 2018 g. ostvario povećan rashod na ime naknade štete zbog izgubljenih sudskih sporova uslijed liječničke pogreške od 19,8\%, te je paralelno evidentirano čak 117 aktivnh parničnih postupaka zbog liječničke pogreške ukupne vrijednosti predmeta spora $65.820 .000,00 \mathrm{kn}$. Iz izvještaja o prihodima i rashodima, primicima i izdacima za KBC Rijeka utvrđeno je da je za 2018 g. ukupni rashod radi naknade štete iznosio $679.756,00 \mathrm{kn}$.

U pogledu iznosa odštetnina koje se u Hrvatskoj dosuđuju za pravomoćno utvrđenu liječničku pogrešku može se zapaziti da sudska praksa nije ujednačena te da dostupni podaci ukazuju na raspon od $80.000,00 \mathrm{kn}$ do čak 5,6 milijuna kuna po ostvarenm lsučaju. Per exemplum, u slučaju pacijenta Opće bolnice u Puli ostvarena je dijagnostička liječnička pogreška koja je uzrokovala polsljedično teške te ireverzibilne zdavstvene posljedice. Pojavni oblik u tom slučaju nestručnog postupanja je bio posebno drastičan sa obilježjem bizarnog, jer je pacijentu pogrešno dijagnosticiran karcinom jednjaka koji mu je potom kirurški odstranjen. U odštetnopravnom postupku je potraživana naknada od 150.000 kuna, međutim bolnica je priznala tužbeni zahtjev do iznosa od $80.000 \mathrm{kn}$. Slično tome, na KBC Rebro je svojedobno zdravoj pacijentici je pogrešno dijagnosticirana psihoza te je nestručno liječena toksičnim medikamentima, a u postupku naknade štete je ostvarila pravo na odštetninu u iznosu od 250.000 kuna.

Hrvatski javni prostor je kontinuirano obilježen nemalim interesom šire javnosti te mediji redovito izvještavju o fenomenološki interesantnim slučajevima liječničkih pogreški s naglaskom na ekonomsku dimenziju. Tako se sa posebnim entuzijazmom izvještava o pojedinim iznosima odštetnina, kao npr., 5,6 milijuna kuna pacijentici koja je uoči rutinske operacije u KBC-u Rijeka zbog pogrešnog uvođenja u anesteziju ostala potpuno nepokretna; 2 milijuna kuna (nepravomoćno) Miroslavu Maškarinu, koji je u rutinskoj operaciji slijepog crijeva u KBC-u Rijeka završio je s amputiranom lijevom potkoljenicom; 3,7 milijuna kuna obitelji dječaka koji je u KB Merkur rođen s teškim oštećenjima zbog gušenja te je ostao nepokretan s tetraparetskim oblikom cerebralne paralize, bez verbalnog i emocionalnoga kontakta, a kuriozitet je da je nestručni porođaj ordinirao privatni liječnik bez ugovora s bolnicom; 3 milijuna kuna obitelji i roditeljima preminule rodilje i njezina nerođenog djeteta koji su bili pacijenti KBC-a Split i županijskog Doma zdravlja; 1,8 milijuna kuna za smrtnu posljedicu pacijentice iz Kutjeva koja je preminule nakon operacije krajnika zbog nemara liječnika Hitne pomoći u Domu zdravlja Požeško-slavonske županije; 1,4 milijuna kuna obitelji pacijentice pakračke bolnice koja je nakon odstranjivanja žučnog mjehura umrla od otklonjive komplikacije - curenja žuči u utrobu; 1,2 milijuna kuna + 4200 kuna na ime mjesečne rente zbog smrti rodilje tijekom porođaja u Klinici za ženske bolesti i porode - KBC Zagreb 
(Petrova); 900.000 kuna pacijentu kojemu je liječničkom pogreškom amputirana potkoljenica, Klinička bolnica Dubrava; 440.000 kuna (nepravomoćno) roditeljima iz Osijeka zbog pogrešnih postupaka u vođenju trudnoće u Klinici za ženske bolesti i porode, - KBC Zagreb (Petrova), a što je uzrokovalo prijevremeni porođaj i smrt djeteta; 250.000 kuna bratu pacijenta koji se liječio u Klinici za psihijatriju Vrapče, gdje je uslijed nestručnog medicinskog tretmana preminuo.(Lider,https:// lider.media/aktualno/strava-u-zdravstvu-deset-najskupljih-liječničkih-pogrešakau-hrvatskoj-119854)

Razvidno je da hrvatski zdravstveni sustav za razliku od analiziranih nije opterećen signifikantnim troškovima na ime popravljana štete pacijentima te da varijacije u iznosima i trendovima u odnosu na pojedine zdravstvene ustanove ne treba pripisati naglašenoj pojavi „lukrativnog parničenja“ već prije ostvarenom stupnju stručne medicinske izvrsnosti u pojedinim zdravstvenim ustanovama. Također, može se uočiti da evidentan pojačan interes javnosti za predmetnom tematikom nije u srazmjeru sa brojem aktualnih parničnih postupaka, napose ako se uzme u obzir činjenica da je Vrhovni sud RH unatrag 10 godina donio manje od ukupno 50 presuda procjenjujući osnovanost građanskopravne odgovornosti za liječničku pogrešku. Valja ipak primijetiti da postoji određena svjesnost o problematici osiguranja od liječničke odgovornosti, a samim time o prisutnim pojavama povrede medicinskog standarda u pružanju usluge, o čemu svjedoči prethodno elaborirano istraživanje EHCI indeksa u segment ocjene stanja liječničke odgovornosti. Osim toga, sasvim izostaju relevantna znanstvena istraživanja te statistika "medicinskih šteta", a tek ponekad javnost biva izviještena o nekim drastičnim slučajevima liječničkih pogreški (npr. slučaj Maškarin), koje ukazuju na imperfektnost sustava. Fenomenologija liječničkih pogreški još uvijek nije kolektivno legitimirana kao bitna tema, a razloge tomu valja prvenstveno tražiti u poljima sociologije, socijalne antropologije i psihologije. U hrvatskom društvu je oduvijek zamjetan opći stav prevladavajućeg poštovanja prema liječničkoj struci kao svojevrsnoj humanitarnoj djelatnosti koja prividno nije u sferi komercijalnog. Tako bi se na hipotetičkoj ljestvici kolektivnog poštovanja, odnos prema liječnicima mogao naći na visokom drugom mjestu, odmah iza točke respekta prema profesionalnim vjerskim službenicima.

Slijedom iznesenog može se zaključiti da hrvatski ekonomsko-pravni realitet s obzirom na problematiku liječnilkih pogreški nije sukladan praksi u referentnim državama koje su usporedno prikazane u radu, jer bez obzira na pojačan interes medija i šire javnosti, Hrvatska nije zabilježila značajniju pojavu sudskog utuženja šteta koje bi bile posljedica povrede medicinskog standarda te objektivna situacija ne upućuje na skoru promjenu trendova. Provedena analiza, ad comparandum, rezultata primjene instituta građanskopravne odgovornosti u zemljama koje su obrađene radom nedvojbeno ukazuje da se situacija u Hrvatskoj prema različitim ekonomsko-financijskim kategorija razlikuje od ostalih promatranih zemalja, kako 
po frekvenciji sudskih postupaka koji su bliže režimu linearne progresije, tako i po prosječnim iznosima odštetnine, te korelativnim akcesornim troškovima. U svjetlu iznijetih okolnosti postavlja se pitanje kakva je daljnja perspektiva te hoće li pro futuro prevagu odnijeti ekonomsko-pravni momenti? Možemo li u Hrvatskoj očekivati "poplavu" tužbi protiv liječnika/zdravstvenih ustanova i kad, te hoće li to i koliko opteretiti financijski sustav sa svim pratećim ekonomskim učincima? Realno je za pretpostaviti da uključenje Hrvatske u ekonomski i pravni prostor EU sa vremenom nosi i prihvaćanje (ili bar prelijevanje) određenih trendova pogotovu onih lukrativnih, a kako vidimo iz situacije u SAD i Italiji, građanskopravna odgovornost za povredu medicinskog standarda može biti unosan posao koji omogućuje prihode znatno širem krugu subjekata od samih oštećenika-pacijenata. U isto vrijeme stvarna mogućnost utuženja štete za oštećenog pacijenta predstavlja stalni poticaj daljnjoj profesionalizaciji obavljanja zdravstvene usluge kako bi se spriječile neželjene posljedice, a čime se konzekventno utječe na porast i održanje kvalitete zdravstvene zaštite. U tom smislu valja uočiti da efikasan odštetnopravni sustav ima učinak generalne prevencije od nastupa štetnih događaja, odnosno, djeluje ex ante, što implicite presumira viši prosječan stupanj ispoljene stručnosti u provođenju svakodnevnih medicinskih tretmana. Važno je u ovom kontekstu istaknuti da hrvatski pravni poredak ustanovljava načelo sigurnosti pacijenata koje se ostvaruje provedbom mjera kojima se svakom pacijentu osigurava pravo na kvalitetnu zdravstvenu zaštitu sukladno njegovom zdravstvenom stanju i općeprihvaćenim stručnim standardima te kojima se sprečavaju štetni neželjeni događaji čija bi posljedica mogla biti smrt ili oštećenje zdravlja pacijenta (Zakon o kvaliteti zdravstvene zaštite i socijalne skrbi, NN 124/11, čl. 5).

\section{ZAKLJUČNE NAPOMENE}

U radu je istražena problematiku ekonomskih implikacija odnosa između liječnika i pacijenta u okolnostima nastanka građanskopravne odgovornosti za liječničku pogrešku. Tematika je raščlanjena kako sa aspekta imperativa ekonomske učinkovitosti koji zahtijeva minimiziranje budućih troškova na ime očekivanih iznosa odštetnina zbog liječničke pogreške, tako i sa aspekta obvezne pravne zaštite prava pacijenata, što se ostvaruje kroz obavljanje medicinskog tretmana sukladno lex artis. Izvođenje osnovne hipoteze rada obuhvatilo je preliminarnu razradu općeg determinacijskog okvira pojma optimalnog profesionalnog standarda zdravstvene skrbi, kako ga shvaća suvremena znanost, pod čime se podrazumijeva utvrđena razina zdravstvene skrbi koja ultimativno rezultira u smanjenju ukupnih društvenih troškova uslijed povrede medicinskog standarda postupanja, kao i štetom koju oštećenik trpi (Shavell, 1987, str. 7). U završnoj analizi bilo je 
potrebno istaknuti kako je opisani model optimalnog standarda posljedica međuzavisnog i sinergijskog djelovanja ekonomskog, pravnog i zdravstvenog sustava koji stoje u horizontalnom odnosu kooperacije.

Provedena analiza ekonomskih učinaka primjene instituta građanskopravne odgovornosti zbog povrede medicinskog standarda, ukazala je da hrvatski propisi iz područja zdravstva prihvaćaju načelo učinkovitosti $i$ djelotvornosti sustava kvalitete zdravstvene zaštite i sigurnosti zdravstvenih postupaka (Zakon o kvaliteti zdravstvene zaštite i socijalne skrbi, čl. 4) koje je zasnovano na teoriji klasičnog modela nezgoda (šteta). Dakle, valja zaključiti kako su u normativnom i teorijskom smislu hrvatsko odštetno i medicinsko pravo inkorporirali suvremene tekovine ekonomske misli i pravnog uređenja u odnosu na predmetnu problematiku, iako, potrebno je upozoriti, postoji nemala diskrepancija u pogledu praktičnih učinaka usporedno sa iskustvima analiziranih zemalja. Neovisno o aktualnom hrvatskom iskustvu, može se općenito ustvrditi kako bi, ex hypothesi, iz skladne implementacije sistemskih mjera koje se izvode iz gore navedenih načela, proizišao upravo onaj željeni optimalan odnos između rezultata obavljenih medicinskih tretmana i troškova nastalih njihovom provedbom, a na čemu inzistira ekonomska znanstvena misao. Slijedom iznesenog, istraživanje je pokazalo da fundamentalni instrumentarij ekonomski učinkovite zdravstvene skrbi u domeni odštetnopravne problematike liječničkih pogreški leži u praktičnoj provedbi pravila dužne pažnje, odnosno, odštetnopravnom sustavu. Na taj način građanskopravna odgovornost za liječničku pogrešku faktično djeluje kao zaštitni mehanizam koji svojim pravnim i ekonomskim posljedicama per consequens oblikuje zdravstveni proces tako što potiče potencijalnog štetnika (liječnik/zdravstvena ustanova) u smjeru pružanja zdravstvene uslugu u režimu standarda optimalne skrbi, imajući na umu da upravo odštetnopravni sustav navedeni standard medicinskog postupanja izjednačuje sa ekonomskom kategorijom optimalne skrbi za pacijenta (Calabresi, 1975; Shavell, 1987). Sukladno tome, tematika ekonomski učinkovite zdravstvene skrbi u kontekstu pružanja zdravstvene usluge razmatrana je kroz prizmu ponašanja liječnika u okviru medicinskog tretmana in abstracto pri čemu mjerilo ponašanja nije bila neka prosječno pametna i pažljiva osoba, nego uobičajeno pažljiv doktor. Preciznije, zahtijevani prosječan standard nije prosječan standard građanina, već prosječan standard koji vrijedi za liječnike određene specijalizacije - bonus pater familias standard (Faure, 2004, str. 19). Pridržavanje navedenog standarda isključuje per se opciju suboptimalnog tretmana koji bi bio suprotan pravilima medicinske profesije, contra legis artis, a čime se preventivno harmoniziraju ekonomsko-financijska, zdravstvena i pravna komponenta.

Potrebno je uočiti kako je optimalan standard medicinske skrbi određen razinom skrbi gdje su granični troškovi medicinske usluge jednaki graničnim koristima po osnovi smanjenja rizika od nastanka štete, pri čemu nepridržavanje ovako defi- 
niranog standarda optimalne skrbi neće biti od ekonomskog interesa za mogućeg štetnika jer bi u slučaju ostvarenja rizika od nastupa štetnog događaja imao dodatne neplanirane financijske izdatke. Neizbježan zaključak je da primjena pravila dužne pažnje u praksi ima povoljne ekonomske učinke sve dok pravni sustav jasno određuje pravno zahtijevanu razinu skrbi (pravni standard dužne pažnje liječnika) kao adekvatnu ekonomski definiranom modelu optimalne zdravstvene skrbi. U pogledu hrvatskog pravnog uređenja, koje je u cijelosti podudarno sa gore iznesenim modelom, od liječnika se očekuje da pri obavljanju medicinske usluge postupa s pažnjom dobrog stručnjaka, odnosno da postupa s povećanom pažnjom, prema pravilima struke i običajima profesije (ZOO, čl. 18 st. 2). Prema tome, hrvatsko pozitivno pravo od medicinskog djelatnika traži da postupa prema standardu dobrog, a ne tek prosječnog stručnjaka, a povredu tako nametnutog profesionalnog standarda određuje kao štetnu radnju s obilježjem protupravnosti u subjektivnom smislu, naravno, uz pretpostavku nastanka pravno relevantne štete. Liječnicima se izrijekom nameće obveza da u provođenju medicinskog tretmana postupaju prema pravilima zdravstvene struke, tako da svojim postupcima ne ugroze život i zdravlje ljudi (Zakon o zdravstvenoj zaštiti, čl. 124 st. 3) te da promiču dostojanstveno i odgovorno profesionalno ponašanje poštivanjem propisa, pravila struke i kodeksa medicinske etike i deontologije (Zakon o liječništvu, NN 121/03, 117/08, čl. 2 st. 2 t. 5).

U zaključnom razmatranju rezultata provedenog istraživanja sublimiranih u završnom prikazu, može se donijeti logičan zaključak o potvrdi postavljene osnovne hipoteze. Naime, sve prethodno izneseno neprijeporno dokazuje hipote$z u$ prema kojoj učinkovita implementacija pravila građanskopravne odgovornosti zbog povrede medicinskog standarda, koja djeluje ex post u uvjetima nastale štete, redovito uzrokuje adekvatnu reakciju liječnika i drugog medicinskog osoblja već ex ante u smjeru primjene zahtijevanog stupnja dužne profesionalne pažnje u aplikaciji odnosnog dijagnostičkog/terapeutskog postupka. U tom smislu može se verificirati višestruko povoljan učinak, s jedne strane, u vidu fenomena generalne prevencije od nastupa štetnih događaja koji uvjetuje viši proječan stupanj ispoljene stručnosti u provođenju medicinskih tretmana, te s druge strane, u blagotvornom djelovanju ostvarenog zahtjeva za naknadu štete kojim se, inter alia, izravno osnažuje ekonomska sfera oštećenika - pacijenta. Razvidno je da odštetnopravni sustav u Hrvatskoj, te usporednim državama, djeluje u funkciji utvrđenja ekonomski učinkovite solucije na način da se temeljni ratio instituta građanskopravne odgovornosti ostvaruje u dvostrukom smislu - (1) u vidu smanjenju troškova ostvarenog štetnog događaja (troškovi štete), te (2) u smanjenju troškova koji nastaju u procesu prevencije štete (troškovi medicinske prevencije).

U radu je potvrđena sporedna hipoteza te je utvrđeno da prema različitim ekonomsko-financijskim kategorijama rezultati primjene instituta građanskopravne odgovornosti u Hrvatskoj, u bitnome odstupaju od ukupnih ekonomskih učinaka koji se ostvaruju u zemljama obuhvaćeni ovim radom, što je rezultanta 
smanjene učestalosti utuženja spornih slučajeva liječničkih pogreški, kao i nižeg prosječnog iznosa odštetnine i korelativnih akcesornih troškova, a što in ultima linea dovodi do komparativno nižeg ukupnog društvenog troška. U tom kontekstu je ustanovljeno da hrvatski zdravstveni sustav, za razliku od analiziranih, nije opterećen signifikantnim troškovima na ime popravljana štete pacijentima te da varijacije u iznosima i trendovima u odnosu na pojedine zdravstvene ustanove ne treba pripisati naglašenoj pojavi „lukrativnog parničenja“ već prije ostvarenom stupnju stručne medicinske izvrsnosti u pojedinim zdravstvenim ustanovama, pri čemu evidentan pojačan interes javnosti za predmetnom tematikom nije u srazmjeru sa brojem aktualnih parničnih postupaka, a objektivna situacija ne upućuje na skoru promjenu trendova.

\section{LITERATURA}

1. Arlen, J. (2010). Contracting over Liability: Medical Malpractice and the Cost of Choice. University of Pennsylvania Law Review, 158, 957-1023.

2. Arlen, J. (2013). Economic Analysis of Medical Malpractice Liability and its Reform. New York University Public Law and Legal Theory Working Papers, Paper 398, 33-68. https://doi.org/10.2139/ssrn.2262792

3. Bevanda, M. (2005). Ugovor između liječnika i pacijenta. Zbornik Pravnog fakulteta Sveučilišta u Rijeci, 26(1), 307-338.

4. Brown v. Lewisham and North Southwark Health Authority, MLC 0081 (CA 1999). Preuzeto 8. 2. 2013. iz http://www.medneg.com/Case/CaseList.aspx

5. Budak, J. (2014). Ocjena pacijenata o kvaliteti rada zdravstvenog osoblja. U M. Vehovec (Ur.), O zdravstvu iz ekonomske perspektive (str. 275-276). Zagreb: Ekonomski institut.

6. BGH, 16. 5. 1972., VersR 1972.

7. BGH, 10. 2. 1987., VI ZR 68/86, JZ 1987.

8. BGH, 29. 11. 1994., Neue Juristische Wochenschrift, br. 12/95, str. 777.

9. Calabresi, G. (1968). Transaction costs, resource location and liability rules: a comment. Journal of Law and Economics, 11(1), 67-73. https://oi.org/ $10.1086 / 466644$

10. Calabresi, G. (1970). The Costs of Accidents: A Legal and Economic Analysis. New Haven: Yale University Press.

11. Calabresi, G. (1975). Optimal Deterrence and Accidents. Yale Law Journal, 84(4), 656-671. 
H. VOJKOVIĆ: Ekonomski učinkovita zdravstvena skrb i liječnička pogreška

12. Cass civ, 1re (Cour de Cassation 4. 11. 1964).

13. Crnić, I. (2009). Odgovornost liječnika za štetu. Zagreb: Organizator.

14. Danzon, P. (1997). Tort Liability: A Minefield for Managed Care? Journal of Legal Studies, 26(2), 491-519. https://doi.org/10.1086/468006

15. Deutsch, E. (1999). Medizinrecht. Berlin; Heidelberg: Springer. https://doi. org/10.1007/978-3-662-08642-1

16. Epstein, R. (1976). Medical Malpractice: The Case for Contract. American Bar Foundation Research Journal, 1(1), 87-149. https://doi.org/10.1086/491804

17. Fattorini, P., Peretti, A., Bergamini, P., \& Valentini, R. (2004). Casistica ortopedica dell'osservatorio GISDI, Medical Malpractice Daily. Medicina legale. Quaderni camerti.

18. Faure, M. (2004). Economic observations concerning optimal prevention and compensation of damage caused by medical malpractice. Tort and Insurance Law, 8, str. 4-87. https://doi.org/10.1007/978-3-7091-0607-5_2

19. Giesen, D. (1988). International Medical Malpractice Law: A Comparative Study of Civil Liability Arising from Medical Care. Tübingen: Mohr.

20. Hamada, K. (1976). Liability Rules and Income Distribution in Product Liability. The American Economic Review, 66(1), 228-234.

21. Hrvatska liječnička komora. (13. 2 2018). Jutarnji list.

22. Klarić, P. (2001a). Odgovornost zdravstvene ustanove i zdravstvenih djelatnika za štetu (drugi dio). Hrvatska pravna revija, 1(9), 31-39.

23. Klarić, P. (2001b). Odgovornost zdravstvene ustanove i zdravstvenih djelatnika za štetu (prvi dio). Hrvatska pravna revija, 1(8), 17-35.

24. Koziol, H. (1984). Österreichisches Haftpflichtrecht (2. izd., Svez. II, Besonder Teil). Wien: Manz.

25. Kullmann, H. J. (1997). Übereinstimmungen und Unterschiede im medizinischen, haftungsrechlichen und sozialversicherungsrechtlichen Begriff des medizinischen Standards. Versicherungsrecht, 48(13), 529-532.

26. Laufs, A., et al. (1999). Handbuch des Arztrechts (2 izd.). München: C. H. Beck.

27. Lewis, M. (2012). Medical malpractice costs continue to climb. Medical Economics, $1-2$.

28. Nikšić, S. (2007). Ugovor o zdravstvenoj usluzi: doktorska disertacija. Sveučilište u Zagrebu, Pravni fakultet. Zagreb.

29. O'Donovan v. Cork County Council [1967] IR 173 (SC)

30. Petrić, S. (2005). Građanskopravna odgovornost zdravstvenih djelatnika. Zbornik Pravnog fakulteta Sveučilišta u Rijeci, 26(1), 81-145. 
31. Pithers v. Leeds Teaching Hospitals NHS Trust, MLC 1152 (QBD 2004). Preuzeto 8. 2. 2013.

32. Radišić, J. (2007). Odgovornost zbog štete izazvane lekarskom greškom u lečenju i u obaveštavanju pacijenata. Beograd: Nomos.

33. Reischauer, R. (1984). § 1299. U P. Rummel (Ur.), Kommentar zum Allgemeinet bürgerlichen Gesetzbuch (Svez. 2). Wien: Manz.

34. Schiemann, G. (1981). Argumente und Prinzipien bei der Fortbildung des Schadensrechts: dargestellt an der Rechtsprechung des BGH. München: C. H. Beck.

35. Shavell, S. (1987). Economic analysis of accident law. Cambridge, Mass.: Harvard University Press.

36. Tarantino, U., Giai Via, A., Macri, E., Eramo, A., Marino, V. i Marsella, L. (2013). Professional Liability in Orthopaedics and Traumatology in Italy. Clinical Orthopaedics and Related Research, 471(10), 3349-3357. https://doi. org/10.1007/s11999-013-3165-6

37. Traina, F. (2009). Medical Malpractice: The Experience in Italy. Clinical Orthopaedics and Related Research,467(2), 434-442. https://doi.org/10.1007/ s11999-008-0582-z

38. Vehovec, M. (2014). Međunarodna usporedba kvalitete zdravstvene zaštite iz perspektive njenih korisnika. U M. Vehovec (Ur.), O zdravstvu iz ekonomske perspektive (str. 283-300 ). Zagreb: Ekonomski institut.

39. Vojković, H. (2013). Građanskopravna odgovornost za liječničku pogrešku: doktorska disertacija. Sveučilište u Zagrebu, Pravni fakultet. Zagreb.

40. World Health Organisation, http://www.euro.who.int/en/health-topics/Healthsystems/patient-safety/data-and-statistics

41. Zakon o liječništvu (NN 121/03, 117/08).

42. Zakon o zdravstvenoj zaštiti (82/13).

\section{ECONOMICALLY EFFECTIVE HEALTH CARE AND MEDICAL MALPRACTICE}

\section{Summary}

The aim of the study was to investigate the relevant economic models that determine the elements of the optimal professional standard of health care, which stand in the substrate of costeffective solutions, especially given the current state and trends in Croatia, as well as comparatively in the USA and Italy. In this sense, the economic effects of applying the civil liability institute due to the violation of the medical standard (medical error) were analyzed, and especially the financial aspect in its totality (cost of damages, medical prevention, total social cost), and the economic models were presented. The study showed that, according to different economic and 
financial categories, the results of the application of civil liability institutes in Croatia significantly deviate from the total economic effects achieved in the countries covered by this work, which is a result of the reduced frequency of litigation of disputed medical errors, as well as lower average compensation and correlative accessory costs, which in ultima linea leads to a comparatively lower total social cost. The research has shown that the fundamental instrument of economically effective health care in the field of compensation of medical errors lies in the practical implementation of the due diligence rules, that is, the compensation system. In this way, civil liability for medical error actually acts as a safeguard that, by its legal and economic consequences, per consequens shapes the health process by encouraging a potential pest (physician / health care institution) to provide health care in an optimal standard of care regime, bearing in mind that it is precisely the system of redress that equates the standard of medical treatment with the economic category of optimal patient care. Therefore, a cost-effective solution should be sought in the harmonious participation of a comprehensive set of systemic measures in health and compensation law, with the aim of reducing the overall social cost of damages due to a medical error while maintaining a general medical standard in the provision of health care.

Key words: economically effective healthcare, liability for medical malpractice, optimal professional standards in healthcare, compensation costs, medical standard of physician 